\title{
II Międzynarodowe Lądzkie Sympozjum Pedagogiczne „Duchowość w pedagogice - pedagogika duchowości” (Ląd nad Wartą, 25 kwietnia 2015 r.)
}

W dniu 25 kwietnia 2015 roku w Wyższym Seminarium Duchownym Towarzystwa Salezjańskiego (WSD TS) w Lądzie nad Wartą odbyło się międzynarodowe sympozjum pedagogiczne. Zorganizowały je dwie współpracujące ze sobą placówki: Wydział Nauk Pedagogicznych Uniwersytetu Kardynała Stefana Wyszyńskiego (WNP UKSW) w Warszawie i wspomniane już lądzkie seminarium duchowne. Patronat nad sympozjum objęli: przełożony Inspektorii św. Wojciecha - ks. dr Marek Chmielewski, Towarzystwo Naukowe Franciszka Salezego i Salezjańskie Stowarzyszenie Wychowania Młodzieży. Spotkanie zgromadziło około osiemdziesięciu uczestników: wykładowców i studentów z Lądu, Warszawy i Eichstätt (Niemcy) oraz salezjanów, siostry zakonne i nauczycieli szkolnych z okolic Lądu.

Otwarcia sympozjum dokonał rektor WSD TS, ks. dr hab. Mariusz Chamarczuk. Sięgając do spuścizny duchowej dawnych mieszkańców opactwa cysterskiego, wprowadził zebranych w temat spotkania. „Człowiek w jedności z naturą odkrywa swoją duchowość. Duchowość zaś jest elementem konstytutywnym człowieka, patrząc na osobę ludzką w sposób nieokrojony" - mówił ks. Chamarczuk. Następnie przywitał gości prodziekan WNP UKSW, ks. dr hab. Dariusz Stępkowski, który moderował pierwszą część.

Sympozjum składało się z trzech części: teoretycznej, praktycznej oraz dyskusji panelowej. Pierwszy wykład, pt. Edukacja religijna w islamie i judaizmie, wygłosił prof. dr hab. Eugeniusz Sakowicz z UKSW. Prelegent zaprezentował najpierw obie religie, ich obecne miejsce w świecie i sytuację na płaszczyźnie socjologicznej. Zwrócił również uwagę na kwestie szczegółowe: pedagogię islamu, rolę świętej księgi, Koranu, oraz edukację religijną w judaizmie i funkcję rodziców w wychowaniu dzieci „dla wieczności”.

Drugie wystąpienie, ks. prof. dra hab. Leonarda Fica - kierownika Katedry Religiologii i Dialogu Międzyreligijnego UKSW, nosiło tytuł Edukacja religijna $w$ hinduizmie i buddyzmie. Prelegent wprowadził uczestników w kontekst kulturowy i religijny podejmowanego tematu, ukazał także elementy, które wpływają na wychowanie w obu religiach, oraz omówił ich główne kierunki edukacji. 
W kolejnym wykładzie ks. dr Zbigniew Babicki podjął temat Duchowy wymiar opieki nad dzieckiem. Autor wyjaśnił definicję duchowości i jej cechy konstytutywne. Pokazał również wpływ duchowości na działalność opiekuńczą nad dziećmi.

Ostatni wykład w tej części sympozjum był zatytułowany Dylemat współczesnej szkoły - religia czy etyka? Ks. dr hab. Dariusz Stępkowski wskazał na alternatywę, jaką Ministerstwo Edukacji dało 25 lat temu, wprowadzając możliwość pobierania nauki religii albo etyki. W dalszym toku swoich rozważań przedstawił wstępne wyniki badań empirycznych przeprowadzonych w 2014 roku wśród 15-latków z Polski, Austrii i Niemiec. Ich celem była ocena kompetencji etyczno-moralnych i religijnych kształtowanych na szkolnych lekcjach religii i etyki w szkołach gimnazjalnych.

Po przerwie jako pierwszy zabrał głos ks. prof. dr hab. Janusz Surzykiewicz związany z dwiema uczelniami: UKSW w Warszawie i Katholische Universität Eichstätt-Ingolstadt (Niemcy). Referent zaprezentował temat Duchowość i religijność a wybór zawodu i orientacja życiowa. W swoim wystąpieniu zwrócił uwagę na przestrzenie naukowe, w których bada się kwestię duchowości człowieka (m.in. teologię, psychologię oraz pedagogikę). Ks. Surzykiewicz wskazał także zebranym argumenty uzasadniające nauczanie i praktykowanie relacji z Bogiem, która jest - jak zauważył prelegent - naturalną potrzebą człowieka. Uzupełnieniem wykładu była prezentacja multimedialna badań przeprowadzonych w Polsce, które szczegółowo omówiła prof. dr Kathrin Maier z Katholische Universität Eichstätt-Ingolstadt (Niemcy).

Następnie wystąpił dr Tomasz Przesławski z Uniwersytetu Warszawskiego, który zapoznał uczestników sympozjum z zagadnieniem zatytułowanym Prawne uwarunkowania funkcjonowania rodziny. Zamknięciem tej części sympozjum była dyskusja, w którą włączyli się prelegenci i goście.

Część druga dotyczyła praktycznej strony obecności duchowości w pedagogice. Moderatorem jej był ks. Zbigniew Babicki. Wśród gości zaproszonych do podzielenia się doświadczeniami wychowawczymi byli: ks. dr Kazimierz Gryżenia, który zaprezentował swoje przemyślenia podczas wystąpienia Religiofobia $w$ procesie destrukcji człowieka, ks. mgr Tomasz Kościelny, który przedstawił problem Rola religii w readaptacji wychowanka zdemoralizowanego, s. mgr Anna Biała z Salezjańskiego Ośrodka Opiekuńczo-Wychowawczego w Dobieszczyźnie, która zabrała głos na temat Wpływ świadectwa wiary wychowawcy na postawy religijne wychowanków placówki socjalizacyjnej. Ostatnim prelegentem był ks. mgr Tadeusz Balicki związany z Salezjańską Organizacją Sportową „Salos” RP, którego wystąpienie nosiło tytuł Przekaz wartości religijnych przez pozytywne środowisko rówieśnicze na przykładzie Salezjańskiej Organizacji Sportowej.

Naukowe spotkanie w Lądzie zakończyło się dyskusją panelową, po której podziękowania uczestnikom w imieniu organizatorów złożyli ks. dr hab. Mariusz Chamarczuk i ks. dr hab. Dariusz Stępkowski.

Podsumowując prezentowane wydarzenie naukowe, można stwierdzić, że całość przebiegła sprawnie i w dobrym klimacie. Należy podkreślić przygotowanie 
prelegentów, którzy w ciekawy i kompetentny sposób przedstawiali referaty. Kwestią zasługującą na uwagę jest także to, że tegoroczne sympozjum, odbywające się po raz drugi w WSD TS, przyjęło formę międzynarodowego wydarzenia naukowego. $\mathrm{Z}$ całą pewnością taka koncepcja sympozjum podnosi jego rangę, a uczestnikom przynosi niekwestionowany pożytek poznawczy. Szkoda jednak, że przeznaczony przez organizatorów czas dla mówców był stosunkowo krótki. Efektem tego było potraktowanie ich tematów w sposób ogólny. Można mieć nadzieję, że wydane materiały pokonferencyjne zrekompensują uczestnikom ewentualny niedosyt.

Ks. Piotr Szlufik Towarzystwo Salezjańskie - Nowicjat, Kutno-Woźniaków 